\title{
The Joint Effects of Body Mass Index and MAOA Gene Polymorphism on Depressive Symptoms
}

\author{
Yangyang Liu ${ }^{凶}$ \\ Department of Psychology, Nanjing University, Nanjing, China
}

The objective of the present study was to examine the joint effects of the body mass index and the MAOA gene polymorphism on depressive symptoms. In two independent Chinese samples, we measured adolescents' depressive symptoms and body mass index and collected their DNA. The results indicated that the main effects of the MAOA gene polymorphism on depressive symptoms were significant. However, the main effects of body mass index and the interaction of the MAOA gene polymorphism and body mass index on depressive symptoms were not significant. By using Chinese adolescents, this study confirmed that the MAOA gene polymorphism directly influenced adolescents' depressive symptoms.

Psychiatry Investig 2015;12(3):408-410

Key Words Body mass index, MAOA, Depressive symptoms, Chinese.

\section{INTRODUCTION}

The occurrence of depression increases dramatically during adolescence. ${ }^{1}$ Furthermore, all over the world, more than $1 / 4$ of adolescents are obese which is usually measured by body mass index (BMI). ${ }^{2}$ Some researchers have proposed that the BMI may influence depressive symptoms through body image. ${ }^{3}$ In empirical research, some studies found that obese and overweight adolescents were more likely to become depressed than normal ones, ${ }^{4,5}$ whereas Wardle et al. ${ }^{6}$ found that low weight was related to more depressive symptoms. Recently, some researchers have proposed that a $\mathrm{u}$ shaped relationship may explain these mixed findings. ${ }^{78}$ Additionally, in previous research, Kress et al.'s ${ }^{9}$ study indicated that no differences existed between overweight and normal weight adolescents in their depressive symptoms.

Moreover, mono-amine-oxidase type A (MAOA) gene has been suggested to be a candidate gene that is associated with depression. ${ }^{10}$ The MAOA gene has a functional polymorphism (2-repeat, 3-repeat, 3.5-repeat, 4-repeat, and 5-repeat), ${ }^{11}$

Received: July 28, 2014 Revised: September 16, 2014

Accepted: October 3, 2014 Available online: July 6, 2015

$\triangle$ Correspondence: Yangyang Liu, PhD

Department of Psychology, Nanjing University, Hankoulu\#22, Nanjing 210093, China

Tel: 86-25-89680959-417, Fax: +86-25-89680950

E-mail: Liuyangyang661@sina.com

(a) This is an Open Access article distributed under the terms of the Creative Commons Attribution Non-Commercial License (http://creativecommons.org/licenses/bync/3.0) which permits unrestricted non-commercial use, distribution, and reproduction in any medium, provided the original work is properly cited. which is based on a 30-bp insertion or deletion. Until now, the empirical findings about the relationship between the MAOA gene polymorphism and depressive symptoms have been mixed. Some studies indicated that the 4-repeat allele carriers were more likely to become depressed than the 3-repeat allele carriers, ${ }^{12,13}$ while some other studies did not find a significant relationship between the MAOA gene polymorphism and depressive symptoms. ${ }^{14,15}$

However, to our knowledge, no study has tested whether the Western findings about the effects of the BMI and the MAOA gene polymorphism can be generalized to Asia adolescents. Therefore, the present study seeks to examine the joint effects of the BMI and the MAOA gene polymorphism on depressive symptoms by using a Chinese sample. It is expected that 1) low weight and obese adolescents both show more depressive symptoms; 2) the 4-repeat allele carriers have more depressive symptoms; 3 ) the MAOA gene polymorphism moderates the relationship between the BMI and depressive symptoms. In previous research, several studies found that gender contributed to depressive symptoms. ${ }^{16-18}$ Hence, we control the effects of gender on depressive symptoms, when analyzing the joint effects of the BMI and the MAOA gene polymorphism on depressive symptoms.

\section{METHODS}

\section{Participants and procedures}

In this study, two independent samples were used. One 
sample (sample 1) consisted of 211 grade 10 students (107 girls). Their mean age was 16.48 years $(\mathrm{SD}=0.56)$. The other sample (sample 2) was used to replicate the findings of sample 1. This sample included 235 grade 10 (102 females) from another three high schools. The mean age of these students was 16.59 years $(\mathrm{SD}=0.67)$. In both samples, students' depressive symptoms were measured and their DNA was collected during classroom time. Their weight and height at grade 10 were measured by trained nurses at school. We received ethical approval from our institution and informed consent was gotten from each participant and one of his/her parents.

\section{Measures}

\section{Depressive symptoms}

Adolescents' depressive symptoms were assessed by using a 10-item shortened version of the Children's Depressive Inventory. ${ }^{19}$ A three-point scale was used, with anchors 1: Never and 2: Always. In this study, the internal consistencies of this scale were acceptable at both samples $(\alpha=0.78$ at sample 1 and $\alpha=0.76$ at sample 2 ).

\section{Body mass index}

Weight $(\mathrm{kg}) /$ height squared $\left(\mathrm{m}^{2}\right)$ was used to compute the BMI.

\section{DNA collection and genotyping}

DNA was extracted from students' cheek cells. Polymerase chain reaction (PCR) was used to amplify the DNA fragment. The primer sequences were 5'-GAACGGACGCTCCATTC GGA-3' (forward) and 5'-ACAGCCTGACCGTGGAGA AG-3' (reverse). The following cycling conditions were used: initial denaturation at $95^{\circ} \mathrm{C}$ for 5 minutes, followed by $35 \mathrm{cy}$ cles at $94^{\circ} \mathrm{C}$ for 30 seconds, $58^{\circ} \mathrm{C}$ for 30 seconds, and $72^{\circ} \mathrm{C}$ for 40 seconds, and finally elongation at $72^{\circ} \mathrm{C}$ for 10 minutes. The length of PCR products was separated by using a $2 \%$ agarose gel electrophoresis. ${ }^{20}$

\section{RESULTS}

In the sample 1, the results indicated that 107 students were the 3-repeat genotype ( 3 or 3/3), 54 students were the 4-repeat genotype (4 or $4 / 4$ ), and 48 students were heterogeneous gen- otype (3/4). In the sample 2 , there were 124 students with only the 3-repeat allele, 68 students with only the 4-repeat allele, and 40 students with the 3/4-repeat genotype. The 2-repeat (1 participant in each sample) and 5-repeat (1 participants in the sample 1 and 2 participants in the sample 2) allele carriers were found as well. As the MAOA gene is on the X chromosome, the phenomenon of gene suppression for females can happen. Similar to the prior studies, ${ }^{20}$ the students with the heterogeneous genotype were eliminated in the next analysis. Moreover, in the sample 1, 26 students were underweight (BMI $\left.<18.5 \mathrm{~kg} / \mathrm{m}^{2}\right), 151$ were normal weight $(\mathrm{BMI}=18.5-24.9 \mathrm{~kg} /$ $\left.\mathrm{m}^{2}\right), 31$ were overweight $\left(\mathrm{BMI}=25.0-29.9 \mathrm{~kg} / \mathrm{m}^{2}\right)$, and 3 were obesity $\left(\mathrm{BMI}>30.0 \mathrm{~kg} / \mathrm{m}^{2}\right) .{ }^{8}$ In the sample 2, 37 students were underweight, 174 were normal weight, 24 were overweight, and 3 were obesity.

Means and standard deviations of students' depressive symptoms in both samples are shown in Table 1. ANOVAs revealed that the main effects of the MAOA gene polymorphism on depressive symptoms were significant [for sample 1, F (1, $153)=4.11, \mathrm{p}<0.05, \eta^{2}=0.03$; for sample 2 , $\mathrm{F}(1,184)=3.97$, $\mathrm{p}<0.05, \eta^{2}=0.02$ ]. However, the main effects of the BMI [for sample $1, \mathrm{~F}(3,153)=0.59$, ns; for sample 2 , $\mathrm{F}(3,184)=2.14$, ns] and the interaction of the MAOA gene polymorphism and the BMI [for sample 1, F $(2,153)=2.24$, ns; for sample 2, F (2, $184)=1.28$, ns] on depressive symptoms were not significant. During analysis, gender was treated as a control variable.

\section{DISCUSSION}

The present study significantly contributes to theory and practices by examining the joint effects of the BMI and the MAOA gene polymorphism on depressive symptoms. Furthermore, two independent samples is another strength of the present study.

In this study, our data partly supported our hypothesis. First, by using a Chinese sample, our data indicated that the MAOA gene as a genetic factor directly contributed to depressive symptoms. ${ }^{13}$ In line with some previous Western studies, ${ }^{13}$ the present study confirms that adolescents with the 4-repeat allele show more depressive symptoms than the 3-repeat allele carriers. Our findings suggest that the links between the MAOA gene polymorphism and depressive symptoms can be generalized to Chinese adolescents. Second, our data showed

Table 1. Mean and SD of depressive symptoms in the sample 1 and 2

\begin{tabular}{ccccccc}
\hline & & & Underweight & Normal weight & Overweight & Obesity \\
\hline Sample 1 & 3-repeat & Mean (SD) & $14.33(3.14)$ & $13.38(1.94)$ & $13.57(2.28)$ & $14.71(2.86)$ \\
& 4-repeat & Mean (SD) & $14.09(1.91)$ & $15.92(3.57)$ & $13.94(0.11)$ \\
Sample 2 & 3-repeat & Mean (SD) & $14.25(2.03)$ & $13.08(1.57)$ & $13.26(2.46)$ & $13.62(0.70)$ \\
& 4-repeat & Mean (SD) & $14.67(0.78)$ & $14.33(1.33)$ & $13.67(0.13)$ \\
\hline
\end{tabular}


that Chinese adolescents' BMI was not significantly related to their depressive symptoms. The present findings provide supportive evidence to the previous findings that showed no differences in depressive symptoms between overweight and normal weight adolescents. ${ }^{9}$ The present findings imply that the Western findings about the significant effects of the BMI on depressive symptoms ${ }^{7,8,21}$ can not be generalized to Chinese adolescents. Hence, to change BMI was not a effective way to reduce Chinese adolescents' depressive symptoms. Third, our data did not show significant interaction of the MAOA gene polymorphism and the BMI. These findings suggest that the MAOA gene polymorphism does not moderate the relationship between the BMI and depressive symptoms. Taken together, our findings suggest that the MAOA gene polymorphism only directly contributes to adolescents' depressive symptoms.

In this study, there are some limitations that could be improved in further research. For instance, the present study was a cross-sectional one. Further research may use a longitudinal design to replicate the present findings. Furthermore, four types of alleles were found in our Chinese sample. However, the number of participants with the 2-repeat and 5-repeat allele was very small. Further research may use a larger sample to examine the joint effects of such alleles and the BMI on depressive symptoms.

\section{REFERENCES}

1. Hankin BL, Abramson LY, Siler M. A prospective test of the hopelessness theory of depression in adolescence. Cogn Ther Res 2001;25:607632.

2. Pabst SR, Negriff S, Dorn LD, Susman EJ, Huang B. Depression and anxiety in adolescent females: the impact of sleep preference and body mass index. J Adolesc Health 2009;44:554-560.

3. Roberts RE, Deleger S, Strawbridge WJ, Kaplan GA. Prospective association between obesity and depression: evidence from the Alameda County Study. Int J Obes Relat Metab Disord 2003;27:514-521.

4. Richardson LP, Garrison MM, Drangsholt M, Mancl L, LeResche L. Associations between depressive symptoms and obesity during puberty. Gen Hosp Psychiatry 2006;28:313-320.

5. Cortese S, Falissard B, Angriman M, Pigaiani Y, Banzato C, Bogoni G, et al. The relationship between body size and depression symptoms in adolescents. J Pediatr 2009;154:86-90.
6. Wardle J, Williamson S, Johnson F, Edwards C. Depression in adolescent obesity: cultural moderators of the association between obesity and depressive symptoms. Int J Obes (Lond) 2006;30:634-643.

7. Revah-Levy A, Speranza M, Barry C, Hassler C, Gasquet I, Moro MR, et al. Association between Body Mass Index and depression: the "fat and jolly" hypothesis for adolescents girls. BMC Public Health 2011; 11:649.

8. de Wit Lam, van Straten A, van Herten M, Penninx B, Cuijpers P. Depression and body mass index, a u-shaped association. BMC Public Health 2009;9:14.

9. Kress AM, Peterson MR, Hartzell MC. Association between obesity and depressive symptoms among U.S. Military active duty service personnel, 2002. J Psychosom Res 2006;60:263-271.

10. Heim C, Plotsky PM, Nemeroff CB. Importance of studying the contributions of early adverse experience to neurobiological findings in depression. Neuropsychopharmacology 2004;29:641-648.

11. Jonsson EG, Norton N, Gustavsson JP, Oreland L, Owen MJ, Sedvall GC. A promoter polymorphism in the monoamine oxidase A gene and its relationships to monoamine metabolite concentrations in CSF of healthy volunteers. J Psychiatr Res 2000;34:239-244.

12. Brummett BH, Krystal AD, Siegler IC, Kuhn C, Surwit RS, Zuchner S, et al. Associations of a regulatory polymorphism of monoamine oxidaseA gene promoter (MAOA-uVNTR) with symptoms of depression and sleep quality. Psychosom Med 2007;69:396-401.

13. Dannlowski U, Ohrmann P, Konrad C, Domschke K, Bauer J, Kugel H, et al. Reduced amygdala-prefrontal coupling in major depression: association with MAOA genotype and illness severity. Int J Neuropsychopharmacol 2009;12:11-22.

14. Lee SY, Hahn CY, Lee JF, Huang SY, Chen SL, Kuo PH, et al. MAOA interacts with the ALDH2 gene in anxiety-depression alcohol dependence. Alcohol Clin Exp Res 2010;34:1212-1218.

15. Tadic A, Rujescu D, Szegedi A, Giegling I, Singer P, Möller HJ, et al. Association of a MAOA gene variant with generalized anxiety disorder, but not with panic disorder or major depression. Am J Med Genet B Neuropsychiatr Genet 2003;117B:1-6.

16. Liu Y, Lu Z. Chinese high school students' academic stress and depressive symptoms: gender and school climate as moderators. Stress Health 2012;28:340-346.

17. Leadbeater BJ, Blatt SJ, Quinlan DM. Gender-linked vulnerabilities to depressive symptoms, stress, and problem behaviors in adolescents. J Res Adolesc 1995;5:1-29.

18. Davies PT, Windle M. Gender-specific pathways between maternal depressive symptoms, family discord, and adolescent adjustment. Dev Psychol 1997;33:657-668.

19. Kovacs M. Children's Depression Inventory Manual. North Tonawanda, NY: Multi-Health Systems; 1992.

20. Liu Y, Lu Z. The relationship between MAOA gene polymorphism and test anxiety. Twin Res Hum Genet 2013;16:1103-1106.

21. Faith MS, Matz PE, Jorge MA. Obesity-depression associations in the population. J Psychosom Res 2002;53:935-942. 